\title{
3' Region
}

National Cancer Institute

\section{Source}

National Cancer Institute. 3' Region. NCI Thesaurus. Code C63582.

Sequences immediately following a point of interest. 